\title{
FAMILY ENTERPRISES IN RURAL AREAS OF THE REPUBLIC OF MACEDONIA
}

\author{
Tošo Kostadinov \\ "Ss. Cyril and Methodius" University in Skopje, Institute of Animal Science, \\ Bul. Ilinden 92-a, Skopje, Skopje, Republic of Macedonia \\ tosokostadinov@gmail.com
}

\begin{abstract}
The aim of this paper is to investigate some aspects of the family enterprises and incorporate new items in the body of knowledge about family businesses in rural areas of the Republic of Macedonia. For this reason a survey on 101 respondents from the rural areas in the Republic of Macedonia was conducted, of which $44.6 \%$ were owners of family enterprises and $55.4 \%$ of non-family businesses. The respondents were offered three sets of statements that are of significance for comparison between family and non-family enterprises and establishment of the particularities of family enterprises in rural areas of the Republic of Macedonia. The answers were valued at a five-degree scale from 1 - unimportant to 5 - priority. From the conducted research it can be concluded that family businesses largely shape the economic environment in rural areas of the Republic of Macedonia. They are unique because of their structure of employees. Employees and managers are not randomly selected but are family members. Their focus on success of their enterprises in future clearly emphasized their desire to stay in the place of residence and to give an active contribution to the development of the local rural community. Support to entrepreneurship and SMEs in general and in rural areas by the state and local governments can significantly stimulate establishment of new family enterprises and the growth of existing ones.
\end{abstract}

Key words: family businesses; non-family businesses; rural areas; advantages of family businesses; weakness of family enterprises

\section{СЕМЕЈНИТЕ ПРЕТПРИЈАТИЈА ВО РУРАЛНИТЕ СРЕДИНИ НА РЕПУБЛИКА МАКЕДОНИЈА}

Целта на овој труд е да се испитат некои аспекти на семејните претпријатија и во корпусот на сознанија за семејните бизниси во руралните подрачја на Република Македонија да се инкорпорираат нови сознанија. За таа цел спроведено е анкетно истражување врз 101 испитаници од руралните подрачја од кои $43.6 \%$ се сопственици на семејни претпријатија, а $55.4 \%$ на несемејни претпријатија на кои им се понудени три сета на понудени одговори кои се од значење за споредба помеѓу семејните и несемејните претпријатија и утврдување на специфичностите на семејните претпријатија во руралните подрачја на Република Македонија. Одговорите се вреднувани по петостепена скала од 1-неважно до 5-приоритет. Од спроведеното истражување може да се заклучи дека семејните бизниси во значителна мерка го обликуваат економскиот амбиент во руралните подрачја на Република Македонија. Тие се уникатни поради нивната структура на вработени. Тоа не се случајно одбрани вработени, менаџери, туку се семејни членови. Нивната насоченост кон успехот на нивното претпријатие во иднината јасно ја потенцира нивната желба да се остане во местото на живеење и да се даде активен придонес кон развој на локалната рурална заедница. Поддршката кон претприемништвото и МСП, воопшто, во руралните подрачја од страна на државата и локалната самоуправа во значителна мерка може да го стимулира основањето на нови семејни претпријатија и раст на веќе постојните.

Клучни зборови: семејни претпријатија; несемејни претпријатија; рурални подрачја; предности на семејните претпријатија; слабости на семејните претпријатија

\section{INTRODUCTION}

Family enterprises represent a significant part of the economy of developed market economies where the share of family businesses among SMEs is between 40 and $50 \%$. Family businesses dominate the structure of enterprises in many European countries. In the U.S.A. family businesses comprise $80 \%$ of all enterprises, realize over $50 \%$ of the GDP and employ more than $50 \%$ of the active business population.

Family businesses have their own advantages and weaknesses. The following can be stated as advantages (Duh 1999): 
They have managers who are members of the family who have a long term observation of the enterprise, which can be seen in the relationship of family members to employees, customers, society and to other stakeholders. Family members want to be proud of the success of their company, they take care of the status of their business in the society and are more committed to the reputation, the enterprise is linked with the name of their family and they are less committed to short-term financial effects if it endangers the family enterprise. Compared with non-family enterprises they are less under pressure of short-term achievements.

The comprehensive knowledge of the company shared by family members is a significant competitive advantage of the family enterprise. They have contacts with the company from their early childhood and the work in it during school holidays provides them opportunities to learn more about the company. This kind of knowledge gives the family member an advantage over other candidates at the entrance in the enterprise. Companies often have a special way of working, as a special technology or "know-how" as well that the competition lacks. It is a kind of knowledge that is developed and kept within the family.

There are clear relationships within the top management of the company. Based on the power given by the ownership, family enterprises have great independence in making decisions, so that decisions can quickly be changed.

The family strongly influences the behavior, norms and values in the enterprise. The values expressed by family members shape common goals for the employees and help achieve a sense of identity and belonging to the enterprise.

Employees have easy access and direct contacts with the top management, members of the family. The personal style of leadership and close contacts with colleagues lead to positive, motivated, business sentiments.

High degree of flexibility enables an individual response to the needs of the market and thus secures a place in the market. The fact that family businesses are usually reliable companies with care and direct relationships with customers and other business partners additionally secures their place on the market. Since managers - family members do not often change, customers have long-term direct relationship with the same person.

The following can be noted among the weaknesses of family businesses:

Funding the growth of the family enterprise is problematic for the following reasons: the share of capital by non-family members is undesirable, while increasing the own share capital by the proprietor - which is entirely depending on the profit is difficult.

Since most managerial positions are kept exclusively for family members, the activities of employees in family enterprises for quality business strength of non-family members are thereby reduced. Thus the opportunities for advancement of non-family members is limited.

The high rate of centralization in decision making and work associated with low rates of formalization and low number of instruments of governance easily lead to overburdened family entrepreneurs. Insufficiently regulated inheritance can jeopardize the existence of the enterprise. It affects the employment and motivation of managers who are not family members. Also, discord and incompetence of individual family members can lead to delays in the decision-making process.

\section{MATERIAL AND METHODS}

The aim of this research is based on literature, documents, and especially based on the analysis of interviewed representative sample of entrepreneurs (101 SMEs), of which $44.6 \%$ are family enterprises and $55.4 \%$ are non-family businesses to get some knowledge relevant to the situation of family businesses in rural areas in the Republic of Macedonia. During the production of this work more commonly used methods in economic analyses were applied, primarily the comparative method, the method of generalization and specialization, the method of induction and deduction and the statistical method.

\section{RESEARCH RESULTS AND DISCUSSION}

The survey respondents were presented three sets of statements that are of significance for comparison between family and non-family enterprises and the assessment of the state of family businesses in rural areas of the Republic of Macedonia, valued at a five-degree scale from 1 - unimportant to 5 - priority (Table 1, Table 2 and Table 3 ).

In the group of statements related to the efforts for improvement of the enterprise to be more competitive in the market, compared by the type of enterprises (family/non-family), respondents from family businesses have more positive attitudes, and there is a significant difference in the assessment of "Association of enterprises from the sector for joint appearance on the market ". 


\section{Table 1}

Agreement with the statements in terms of improving the work for better competitive market position, compared with the type of enterprises (family/non-family)

\begin{tabular}{lccc}
\hline \hline & $\begin{array}{c}\text { Family } \\
\text { Mean value }\end{array}$ & $\begin{array}{c}\text { Non-Family } \\
\text { Mean value }\end{array}$ & $\begin{array}{c}\text { Total } \\
\text { Mean value }\end{array}$ \\
\hline Improving the quality of products and services & 4.22 & 4.19 & 4.17 \\
Improving the promotion of products & 4.15 & 4.24 & 4.20 \\
Obtaining certifications for quality & 3.84 & 4.19 & 4.03 \\
Professional consulting assistance & 3.53 & 3.40 & 3.46 \\
Improvement and education in the field of entrepreneurship & 3.75 & 3.90 & 3.83 \\
Improvement and education in the field of IT & 3.73 & 4.00 & 3.89 \\
Improvement and education in the field of management & 3.73 & 3.91 & 3.83 \\
Improvement and education in finance & 3.47 & 3.81 & 3.66 \\
Improvement and education in the field of sales & 3.80 & 3.96 & 3.89 \\
Improvement and education in marketing & 3.91 & 3.91 & 3.91 \\
Improvement and education in foreign languages & 3.38 & 3.38 & 3.38 \\
Association with companies in the sector to jointly appear on the market & 3.69 & 3.11 & 3.37 \\
Assistance from development programs through grants & 4.4 & 4.23 & 4.31 \\
Assistance from development programs through favorable loans & 4.38 & 4.23 & 4.30 \\
Assistance from development programs through guarantee funds & 3.78 & 3.82 & 3.80 \\
\hline \hline
\end{tabular}

Source: own calculations

Table 2

Agreement with the statements in terms of business plans for the future, compared with the type of the enterprise (family / non-family)

\begin{tabular}{lccc}
\hline \hline & Family & Non-Family & Total \\
\cline { 2 - 4 } & Mean value & Mean value & Mean value \\
\hline Introducing new products or services & 4.00 & 4.14 & 4.08 \\
Sales on a new market & 3.62 & 3.16 & 3.37 \\
Exploring new markets & 3.69 & 3.02 & 3.32 \\
Search for new distribution channels & 3.91 & 3.38 & 3.61 \\
Expanding advertising and promotion & 4.02 & 3.75 & 3.87 \\
Investing in new equipment and machinery & 4.07 & 3.39 & 3.69 \\
Replacement of current equipment and machinery & 4.07 & 3.46 & 3.73 \\
Expansion of current facilities & 4.09 & 3.36 & 3.68 \\
Redesign/new arrangement of the current facilities & 3.75 & 3.16 & 3.42 \\
Search for additional financial capital & 4.24 & 3.66 & 3.92 \\
Computerization of current operations & 3.73 & 2.93 & 3.29 \\
Upgrading of computer systems & 3.76 & 3.07 & 3.38 \\
Redesign of work activities & 3.73 & 2.93 & 3.29 \\
Expanding the scope of work activities & 4.02 & 3.57 & 3.77 \\
Search for professional or technical advice & 3.87 & 3.13 & 3.46 \\
Additional engagement of staff specialists & 3.82 & 3.02 & 3.38 \\
Investing in staff training (elsewhere / not in the company) & 2.93 & 2.39 & 2.63 \\
\hline \hline
\end{tabular}

Source: own calculations 
Regarding statements about plans for the business in future, compared with the type of enterprise (family/non-family), the highest score was obtained for the claim "Adding a new product or service," and that by representatives of non-family companies. In family businesses the need to seek additional financial capital, and hiring staff specialists, redesign of work activities, computeri- zation of current operations, upgrading computer systems, investing in staff training (to another place/not in the company) expansion of business activities, sales of new markets, finding new distribution channels, expanding current facilities are emphasized. The obtained results show more proactive behaviour of family enterprises for the future as opposed to non-family companies.

Table 3

Agreement with the statements about entrepreneurship, compared with the type of enterprises (family/non-family)

\begin{tabular}{|c|c|c|c|}
\hline & $\begin{array}{c}\text { Family } \\
\text { Mean value }\end{array}$ & $\begin{array}{l}\text { Non-Family } \\
\text { Mean value }\end{array}$ & $\begin{array}{c}\text { Total } \\
\text { Mean value }\end{array}$ \\
\hline My business is the most important activity in my life & 4.18 & 4.09 & 4.13 \\
\hline I would do everything that is needed for my business to succeed & 4.18 & 4.18 & 4.18 \\
\hline I plan to sell my business at the end & 2.20 & 2.11 & 2.15 \\
\hline $\begin{array}{l}\text { I would like to significantly contribute to the community by developing a successful } \\
\text { business }\end{array}$ & 4.33 & 4.25 & 4.29 \\
\hline $\begin{array}{l}\text { I would prefer to have my own business than to earn higher wages working for } \\
\text { someone else }\end{array}$ & 4.27 & 3.95 & 4.12 \\
\hline To run your own business is more important than have more time for the family & 3.62 & 3.95 & 3.80 \\
\hline I would prefer to have my own business than to have another promising career & 3.98 & 4.16 & 4.08 \\
\hline $\begin{array}{l}\text { For the entrepreneur it is important to understand and accept the risk in order to start } \\
\text { and run a successful business }\end{array}$ & 4.22 & 4.29 & 4.26 \\
\hline I am ready to get into conflict with my family for the sake of running my business & 3.60 & 3.79 & 3.70 \\
\hline I would put my house mortgaged to acquire capital for my business & 3.60 & 3.46 & 3.52 \\
\hline I would be ready to have less security for my family in order to run my business & 3.58 & 3.75 & 3.67 \\
\hline I run my business to continue the family tradition & 3.51 & 3.20 & 3.34 \\
\hline I run my business to contribute to the welfare of my relatives & 3.49 & 3.55 & 3.52 \\
\hline I run my business to live in a place that my family likes & 3.38 & 3.54 & 3.47 \\
\hline I run my business to improve the status and prestige of my family & 4.00 & 4.04 & 4.02 \\
\hline I run my business to have more flexibility in my personal and family life & 3.93 & 4.20 & 4.08 \\
\hline
\end{tabular}

Source: own calculations

In the group of questions concerning attitudes toward entrepreneurship, compared with the type of enterprises (family/non-family), the largest number of respondents with family businesses emphasize that they would like to contribute significantly to the community through the development of a successful business. The lowest assessment was given by representatives with non-family companies in view that at the end they plan to sell the business. The biggest difference in the assessments given by the respondents is about the atti- tude 'I run my business to have more flexibility in my personal and family life', and the same attitude was better valued by the representatives of nonfamily enterprises.

This research has shown that family businesses largely shape the economic environment in rural areas of the Republic of Macedonia. They are unique because of their structure of employees, since they are not randomly selected employees and managers, but are family members. Their focus on the success of their enterprise in future 
clearly emphasizes their desire to stay in the place of residence and to contribute to the development of the local rural community. The future of family enterprises in rural areas among others depends on how successfully the legacy of leadership and ownership will be addressed. General support to entrepreneurship and SMEs by the state and local governments in rural areas can considerably stimulate establishment of new family enterprises and growth of the existing ones.

\section{CONCLUSION}

Family enterprises represent a significant part of the economy of developed market economies where the share of family businesses among SMEs is between $40-50 \%$. Family businesses dominate the structure of enterprises in many European countries. In the U.S.A. family businesses comprise $80 \%$ of all enterprises, realize over $50 \%$ of the GDP and employ more than $50 \%$ of the active business population.

From the conducted research it can be concluded that family businesses largely shape the economic environment in the rural areas of the Republic of Macedonia. They are unique because of their structure of employees, who are not randomly selected employees/managers, but family members.

Their focus on the success of their enterprise in future clearly emphasizes their desire to stay in the place of residence and to give active contribution to the development of the local rural community. The support to entrepreneurship and SMEs in general and in rural areas by the state and local governments can significantly stimulate the establishment of new family enterprises and growth of the existing ones.

\section{REFFERENCES:}

[1] Crane, M. (1982): How to keep Families from Feuding In INC,

[2] Danco, L. (1980): Inside the Family Business. Center for Family Business.

[3] Duh, M. (1999): Razvojne posebnosti druzinskega podjetja. Doktorska disertacija, Ekonomsko poslovnog fakulteta, Maribor.

[4] Handler, W. (1992): The Family Venture. In The Entrepreneurial Venture, selected by Salman W., Stevenson H., Harvard School Publications, Boston, Massachusetts.

[5] Lansberg, M. (1998): The Succession Conspiracy In: Family Business Review.

[6] Morris, B. E. (2001): Keeping it in the family. Business First of Louisville.

[7] Topolnicki, E. (1983): Family Firms Can Leave the Feuds Behind In: Money. 